\title{
Perbedaan Kadar Keasaman Saliva Pasca Menyikat Gigi dengan Sikat Gigi Konvensional dan Sikat Siwak
}

\author{
${ }^{1}$ Billie A. F. P. Mo'o \\ ${ }^{2}$ Lydia E. N. Tendean \\ ${ }^{1}$ Christy N. Mintjelungan \\ ${ }^{1}$ Johanna A. Khoman \\ ${ }^{1}$ Program Studi Pendidikan Dokter Gigi Fakultas Kedokteran \\ ${ }^{2}$ Bagian Biologi Fakultas Kedokteran \\ Universitas Sam Ratulangi Manado \\ Email: billiearta@gmail.com
}

\begin{abstract}
Miswak (Salvadora persica) is known to be capable enough to increase the hygiene and oral health through its mechanical and chemical components. The acidity of saliva is one of the components that contribute to the acidity of the oral cavity. This study was aimed to evaluate the difference of the saliva acidity after tooth brushing using conventional toothbrush and miswak brush. This was an observational descriptive study with a cross sectional design. Population consisted of Preclinic students of Dentistry Study Program, Sam Ratulangi University Manado. Total sampling method was used in this study and we obtained 30 students that fulfilled the inclusion criteria. The result showed that the number of subjects with acid category of saliva was higher after using miswak brush $(53.3 \%)$ than after using conventional toothbrush (23.3\%). In conclusion, the acid category of saliva was more frequent occured afer tooth brushing with miswak brush than with conventional toothbrush.
\end{abstract}

Keywords: acidity of saliva, conventional toothbrush, miswak brush

\begin{abstract}
Abstrak: Siwak (Salvadora persica) telah dikenal mampu meningkatkan kebersihan dan kesehatan mulut melalui kandungan komponen mekanis serta komponen kimia. Kadar keasaman saliva merupakan salah satu komponen yang berkontribusi terhadap kadar keasaman mulut. Penelitian ini bertujuan untuk mengevaluasi perbedaan kadar keasaman saliva pasca menyikat gigi dengan sikat gigi konvensional dan sikat siwak. Jenis penelitian ialah deskriptif observasional dengan desain potong lintang. Populasi ialah mahasiswa Preklinik Program Studi Pendidikan Dokter Gigi Universitas Sam Ratulangi (PSPDG Unsrat) Manado. Metode pengambilan sampel ialah total sampling. Pada penelitian ini didapatkan 30 mahasiswa yang memenuhi kriteria inklusi. Setiap subyek dinilai kadar keasaman saliva sebelum dan setelah menyikat gigi dengan sikat gigi konvensional dan sikat siwak. Hasil penelitian mendapatkan jumlah subyek dengan nilai kadar keasaman saliva kategori asam setelah menyikat gigi menggunakan sikat siwak $(53,3 \%)$ lebih besar daripada setelah menyikat dengan sikat gigi konvensional $(23,3 \%)$. Simpulan penelitian ini ialah kadar keasaman saliva kategori asam setelah menyikat gigi dengan sikat siwak lebih sering ditemukan daripada yang menggunakan sikat gigi konvensional.
\end{abstract}

Kata kunci: kadar keasaman saliva, sikat gigi konvensional, sikat siwak

Kesehatan gigi dan mulut merupakan bagian dari kesehatan tubuh secara keseluruhan dan dapat berdampak pada kesehatan secara umum. Terganggunya fungsi bicara, pengunyahan, dan estetik akibat gangguan kesehatan gigi dan mulut dapat memengaruhi kualitas hidup. Kesehatan gigi dan mulut merupakan hal yang perlu mendapat 
perhatian serius dari pemerintah dan tenaga kesehatan gigi. Hal ini disebabkan karena tingginya angka kejadian masalah gigi dan mulut di Indonesia, yakni sekitar 90\% penduduk menderita penyakit gigi dan mulut. Berdasarkan Riset Kesehatan Dasar (RISKESDAS) pada tahun 2018, masalah gigi dan mulut di Indonesia sebesar 57,6\% dan khususnya di Provinsi Sulawesi Utara sebesar $65 \% .^{1-3}$

Terdapat bermacam cara dalam menjaga kesehatan gigi dan mulut yaitu menyikat gigi yang dapat merangsang aliran saliva sehingga meningkatkan kapasitas buffer saliva yang berfungsi untuk menjaga kesehatan dalam rongga mulut. Saliva merupakan salah satu bahan yang digunakan dalam pertahanan tubuh yang disekresikan oleh tiga pasang kelenjar utama yang mengandung $99,5 \% \mathrm{H}_{2} \mathrm{O}$ serta $0,5 \%$ elektrolit dan protein. ${ }^{4}$ Saliva menyekresikan dua jenis cairan utama yaitu sekresi serosa yang mengandung ptialin sebagai enzim yang mencerna makanan dan mukus yang mengandung musin sebagai pelindung permukaan mukosa rongga mulut. ${ }^{5}$

Salah satu bahan yang bisa digunakan untuk menyikat gigi yaitu sikat siwak. Siwak merupakan tumbuhan yang memiliki kandungan alami antimikroba yang berefek terhadap bakteri karies dan bakteri periodontal. ${ }^{6}$ Efek bakterisida pada kayu siwak dihasilkan oleh kandungan tiosianat (SCN-) dan alkaloid yang merupakan salvadorin yang dapat mengatur kadar keasaman rongga mulut dan menstimulasi gingiva. Ekstrak siwak mengandung klorida yang tinggi dan kalsium yang memengaruhi peningkatan kadar keasaman saliva rongga mulut.

Berdasarkan latar belakang di atas, maka penulis tertarik untuk mengetahui perbedaan kadar keasaman saliva pasca menyikat gigi dengan sikat gigi konvensional dan sikat siwak.

\section{METODE PENELITIAN}

Penelitian ini dilaksanakan di Program Studi Pendidikan Dokter Gigi Universitas Sam Ratulangi (PSPDG UNSRAT) pada bulan Mei 2019. Tujuan penelitian ialah untuk mengetahui perbedaan kadar keasaman saliva pasca menyikat gigi dengan sikat gigi konvensional dan sikat siwak. Jenis penelitian ialah deskriptif observasional dengan desain potong lintang.

Populasi penelitian yaitu seluruh mahasiswa Preklinik di PSPDG Unsrat yang berjumlah 97 orang. Teknik pengambilan sampel yang digunakan ialah metode total sampling. Seluruh mahasiswa Preklinik yang memenuhi kriteria inklusi dijadikan subjek penelitian.

Sebelum penelitian, subyek penelitian menandatangani informed consent pada hari penelitian dan dikumpulkan pada hari yang sama. Subyek dipastikan sudah menyikat gigi dan tidak mengonsumsi makanan 1 jam sebelum penelitian dilaksanakan. Subyek diperiksa dengan cara meletakkan kertas lakmus di dalam wadah yang berisi salivanya selama 3 detik pada setiap perlakuan untuk mendapatkan nilai kadar keasaman saliva.

Masing-masing subyek diukur kadar keasaman saliva awal, kemudian diberi satu buah roti (roti tanpa keju atau coklat) untuk dikonsumsi. Setengah jam kemudian, subyek diinstruksikan untuk menyikat gigi dengan sikat gigi konvensional dan diperiksa kadar keasaman salivanya. Setelah itu, subyek yang sama diinstruksikan untuk mengonsumsi satu buah roti lagi. Setengah jam kemudian, subyek diinstruksikan untuk menyikat gigi dengan sikat siwak dan diperiksa kadar keasaman salivanya. Data yang diperoleh diolah dan dianalisis serta disajikan dalam bentuk tabel distribusi frekuensi.

\section{HASIL PENELITIAN}

Populasi penelitian ini yaitu seluruh mahasiswa Preklinik PSPDG UNSRAT yang berjumlah 97 orang. Jumlah mahasiswa yang memenuhi kriteria inklusi ialah 30 orang.

Berdasarkan jenis kelamin didapatkan subyek berjenis kelamin perempuan sebanyak 23 orang $(76,7 \%)$ dan yang berjenis kelamin laki-laki sebanyak 7 orang $(23,3 \%)$. 
Tabel 1 memperlihatkan bahwa berdasarkan usia didapatkan jumlah subyek terbanyak berusia 21 tahun yaitu 13 orang $(43,3 \%)$, sedangkan yang paling sedikit ialah berusia 23 tahun yaitu 1 orang $(3,4 \%)$

Tabel 1. Karakteristik subyek berdasarkan usia

\begin{tabular}{ccc}
\hline Usia (tahun) & $\mathbf{n}$ & $\mathbf{\%}$ \\
\hline 18 & 6 & 20,0 \\
19 & 3 & 10,0 \\
20 & 3 & 10,0 \\
21 & 13 & 43,3 \\
22 & 4 & 13,3 \\
23 & 1 & 3,4 \\
Total & 30 & 100 \\
\hline
\end{tabular}

Tabel 2 menunjukkan bahwa sebelum menggunakan sikat gigi konvensional subyek terbanyak memiliki nilai kadar keasaman saliva normal yaitu 20 orang $(66,7 \%)$ sedangkan nilai kadar keasaman saliva asam yaitu 10 orang $(33,3 \%)$ dan nilai kadar keasaman saliva basa yaitu 0 orang $(0 \%)$. Setelah menggunakan sikat gigi konvensional, subyek terbanyak memiliki nilai kadar keasaman saliva normal yaitu 21 orang $(70,0 \%)$ sedangkan yang memilki nilai kadar keasaman saliva asam telah berkurang yaitu 7 orang $(23,3 \%)$; dan nilai kadar keasaman saliva basa yaitu 2 orang $(6,7 \%)$.

Tabel 2. Distribusi frekuensi kadar keasaman saliva menggunakan sikat gigi konvensional

\begin{tabular}{lcccc}
\hline Kategori & \multicolumn{3}{c}{$\begin{array}{c}\text { Penggunaan sikat gigi } \\
\text { konvensional }\end{array}$} \\
& $\begin{array}{c}\text { Sebelum } \\
\text { menyikat }\end{array}$ & $\begin{array}{c}\text { Setelah } \\
\text { menyikat }\end{array}$ \\
& $\mathrm{n}$ & $\%$ & $\mathrm{n}$ & $\%$ \\
Normal & 20 & 66,7 & 21 & 70,0 \\
Asam & 10 & 33,3 & 7 & 23,3 \\
Basa & 0 & 0 & 2 & 6,7 \\
Total & 30 & 100 & 30 & 100 \\
\hline
\end{tabular}

Tabel 3 menunjukkan bahwa kadar keasaman saliva subyek sebelum menggunakan sikat siwak terbanyak memiliki nilai kadar keasaman saliva normal yaitu 21 orang $(70,0 \%)$ sedangkan nilai kadar keasaman saliva asam yaitu 7 orang $(23,3 \%)$, dan kadar keasaman saliva basa yaitu 2 orang $(6,7 \%)$. Setelah menggunakan sikat siwak, subyek terbanyak memiliki nilai kadar keasaman saliva asam yaitu 16 orang $(53,3 \%)$ sedangkan subyek dengan nilai kadar keasaman saliva normal bertambah menjadi 16 orang $(43,3 \%)$; dan nilai kadar keasaman saliva basa yaitu sebanyak 1 orang $(3,4 \%)$.

Tabel 3. Distribusi frekuensi kadar keasaman saliva menggunakan sikat siwak

\begin{tabular}{lcccc}
\hline Kategori & \multicolumn{2}{c}{$\begin{array}{c}\text { Penggunaan sikat siwak } \\
\text { Sebelum } \\
\text { menyikat }\end{array}$} & $\begin{array}{c}\text { Setelah } \\
\text { menyikat }\end{array}$ \\
\hline Normal & $\mathrm{n}$ & $\%$ & $\mathrm{n}$ & $\%$ \\
Asam & 21 & 70,0 & 13 & 43,3 \\
Basa & 7 & 23,3 & 16 & 53,3 \\
Total & 2 & 6,7 & 1 & 3,4 \\
& 30 & 100 & 30 & 100 \\
\hline
\end{tabular}

\section{BAHASAN}

Subyek penelitian ini berjumlah 30 orang mahasiswa Preklinik PSPDG Unsrat, terdiri dari 23 orang perempuan $(76,7 \%)$ dan 7 orang laki-laki (23,3\%). De Almeida et al $^{8}$ menyatakan bahwa laju aliran saliva pada jenis kelamin laki-laki lebih tinggi dibandingkan perempuan karena laki-laki memiliki kelenjar saliva yang lebih besar. Hasil penelitian ini menunjukkan bahwa terdapat perbedaan kadar keasaman saliva pasca menyikat gigi dengan sikat gigi konvensional dan sikat siwak.

Sikat gigi merupakan salah satu alat fisioterapi mulut yang digunakan secara luas untuk membersihkan gigi dan mulut. Walaupun tersedia berbagai sikat gigi di pasaran, namun harus diperhatikan keefektifan sikat gigi untuk membersihkan gigi dan mulut, di antaranya tekstur bulu sikat lembut tetapi cukup kuat, ukuran bulu sikat disesuaikan dengan penggunanya, dan ujung bulu-bulu sikat membulat. ${ }^{9}$

Diet kaya akan karbohidrat dapat menurunkan kapasitas buffer saliva karena adanya karbohidrat dapat meningkatkan produksi asam oleh bakteri. Kapasitas buffer dapat meningkat jika banyak mengonsumsi diet kaya akan protein dan sayuran. Bakteri memanfaatkan protein sebagai sumber makanan sehingga meng- 
hasilkan zat-zat yang bersifat basa seperti amoniak. $^{10}$

Siwak merupakan tumbuhan dengan kandungan alami antimikroba yang memberikan efek terhadap bakteri karies dan bakteri periodontal. ${ }^{6}$ Siwak mengandung kurang lebih 19 zat, yang dibutuhkan untuk meningkatkan kesehatan mulut. Kandungan siwak antara lain bahan antiseptik, asam tanat yang bersifat astringensia, dan minyak atsiri yang meningkatkan produksi saliva. $^{11}$

Hasil analisis kandungan batang kayu siwak kering dengan menggunakan etanol $80 \%$ dilanjutkan dengan eter kemudian kandungannya diteliti melalui prosedur kimia exhaustive chemical procedure (ECP) menunjukkan bahwa siwak mengandung zat-zat kimia seperti: trimetilamin, alkaloid yang diduga sebagai salvadorin, klorida, sejumlah besar fluorida dan silika, sulfur, vitamin $\mathrm{C}$, tanin, saponin, flavonoid dan sterol. ${ }^{12}$ Kandungan tanin (asam tanan) dalam siwak dapat mengurangi perlekatan bakteri pada permukaan gigi. Flavonoid berfungsi untuk membersihkan gigi, memutihkan serta menyehatkan gigi dan gusi. ${ }^{13,14}$ Siwak berfungsi dalam menjaga kesehatan rongga mulut melalui berbagai cara. Hal tersebut dapat melalui mekanik yaitu dengan menggunakan siwak secara langsung sebagai pengganti sikat gigi, atau bisa melalui kandungan kimiawinya yaitu antara lain dengan menggunakan siwak dalam bentuk ekstrak. $^{15}$

Penelitian terhadap kayu siwak membuktikan bahwa siwak mengandung mineral-mineral alami yang dapat membunuh dan menghambat pertumbuhan bakteri, mengikis plak, mencegah gigi berlubang, serta memelihara kesehatan gusi dan jaringan pendukung gigi. ${ }^{16}$

Hasil penelitian Sofrata et $\mathrm{al}^{16}$ melaporkan bahwa potensi kayu siwak selain bersifat mekanik juga bisa bersifat sebagai antibakteri, antikulat, dan antiplak yang dapat membantu mencegah masalah gigi dan mulut seperti penumpukan plak, bau mulut, gigi berlubang, dan penyakit periodontal termasuk di antaranya ialah gingivitis.
Sikat siwak menggabungkan dua fungsi dalam satu pemakaian yaitu efek sikat dan pasta gigi. Siwak dapat menghasilkan efek mekanik dan biologi. Kandungan minyak esensialnya yaitu Salvadora persica mempunyai efek antibakteri dan dapat meningkatkan stimulasi aliran saliva. ${ }^{8,17,18}$ Rasa siwak sedikit pahit dan pedas yang terdapat pada minyak esensial siwak secara efektif dapat menstimulasi sekresi aliran saliva dan meningkatkan kapasitas buffer saliva. ${ }^{7}$

Nilai kadar keasaman saliva asam setelah menyikat gigi dengan sikat siwak dapat disebabkan karena subyek telah mengonsumsi roti sebelumnya dan sikat siwak tidak dapat membersihkan secara maksimal gigi bagian belakang. Nilai kadar keasaman saliva normal setelah menyikat gigi dengan sikat siwak disebab-kan karena terdapat subyek yang telah membersihkan gigi dengan sikat gigi konvensional sebelumnya dan subyek lebih mengetahui cara menyikat gigi dengan sikat gigi konvensional daripada menggu-nakan sikat siwak.

Hasil penelitian ini memperlihatkan terdapatnya perbedaan nilai kadar keasaman saliva pasca menyikat gigi dengan sikat gigi konvensional dan sikat siwak, yaitu kadar keasaman saliva kategori asam lebih sering didapatkan pada subyek setelah menyikat gigi dengan sikat siwak. Diduga hal ini disebabkan karena fungsi sikat siwak belum maksimal dalam membersihkan rongga mulut karena bentuk sikat siwak belum ideal dan subyek penelitian belum pernah menggunakan sikat siwak sebelumnya.

\section{SIMPULAN}

Berdasarkan hasil penelitian ini dapat disimpulkan bahwa subyek dengan kadar keasaman saliva kategori asam pasca menyikat gigi dengan sikat siwak lebih banyak daripada yang menggunakan sikat gigi konvensional. Diduga dalam penelitian ini, fungsi sikat siwak belum maksimal karena bentuk sikat siwak belum ideal dan subyek penelitian belum pernah menggunakan sikat siwak sebelumnya. 
Bagi peneliti lanjut dianjurkan menggunakan variabel yang berbeda dengan menyempurnakan bentuk sikat siwak. Selain itu, diperlukan uji klinis lanjut agar sikat siwak bisa dimanfaatkan menjadi tanaman berkhasiat obat yang dapat digunakan untuk membersihkan gigi.

\section{DAFTAR PUSTAKA}

1. Eliza H, Tati SI, Sri A. Pendidikan Kesehatan Gigi. Jakarta: EGC, 2012; p. 118.

2. Riskesdas 2018. Laporan Nasional. Jakarta: Kementerian Kesehatan Republik Indonesia; 2018.

3. Erna G. Perbedaan pembersihan gigi menggunakan kayu siwak (Salvadora persica), sikat gigi dengan pasta gigi ekstrak siwak dan non herbal terhadap penurunan plak [Tesis]. Yogyakarta: FKG UMY; 2012.

4. Sherwood L. Fisiologi Manusia dari Sel ke Sistem (6th ed). Jakarta: EGC, 2012; p. 625-50.

5. Guyton AC, Hall JE. Textbook of Medical Physiology (12th ed). Jakarta: Elsevier, 2011; p. 839-40.

6. Sabrina. Pemanfaatan ekstrak batang siwak (Salvadora persica) sebagai larutan kumur dengan penambahan ekstrak jeruk nipis dan stroberi. FKIP UMS, Surakarta. [serial online] 2015 [cited 2019 March]. Available from: http: //eprints.ums.ac.id/34200/1/NASKAH $\%$ 20PUBLIKASI.pdf.

7. Halawany HS. A review on miswak (Salvadora persica) and its effect on various aspects of oral health. Saudi Dent J. 2012;24(2):63-9.

8. De Almeida PDV, Gregio AMT, Machado MAN, de Lima AA, Azevedo LR. Saliva composition and functions: a comprehensive review. J Contemp Dent Pract. 2008;(9)3:72-80.

9. Putri MH, Herijulianti E, Nurjanah N. Ilmu Pencegahan Penyakit Jaringan Keras dan Jaringan Pendukung Gigi. Jakarta: ECG, 2011; p. 1, 56-77, 107-9.

10. Amerongen AV. Ludah dan Kelenjar Ludah (terj.). Yogyakarta: Gadjah Mada University Press, 1992; p. 37-41.

11. Ramadhani AF. Potensi antimikroba kayu siwak (Salvadora persica Wall.) terhadap Staphylococcus aureus dan Pseudomonas aeruginosa serta aplikasi pada bakso daging. [serial online] 2013 [cited 2019 March]. Available from: http://repository.ipb.ac.id/jspui/bitstrea m/123456789/66961/1/F13afr.pdf.

12. Darout IA. Antimicrobial anionic component in miswak extract. Bergen: Dept. Odontology, Faculty of Dentistry University of Bergen; 2000.

13. Mahanani ES, Samuel SV. Miswak (Salvadora persica) as a cleansing teeth. [cited 2019 March]. Available from: http://jurnal.pdii.lipi.go.id/admin/ jurnal/71073842.pdf.

14. Suryani L, Astuti Y. Uji kadar hambatan minimal ekstrak batang siwak (Salvadora persica) terhadap Staphylococcus aureus secara in vitro. [cited 2019 March]. Available from: http://jurnal. pdii.lipi.go.id/admin/jurnal/7107712.pd f.

15. Houwink B. Karies Gigi. In: Ilmu Kedokteran Gigi Pencegahan. Suryo S, editor. Yogyakarta: Gadjah Mada University Press, 1993; p. 110-6; 125-6; 175-277.

16. Sofrata AH, Claesson RL, Lingstrom PK, Gustaffsson AK. Strong antibacterial effect of miswak againts oral microorganisms associated with periodontitis and caries. J Periodontol. 2008;79(8): 1474-9.

17. Al-Bayaty FH, Al-Koubaisi AH, Ali NAW, Abdulla MA. Effect of mouth wash extracted from Salvadora persica (miswak) on dental plaque formation: a clinical train. Journal of Medicinal Plants Research. 2010;4(14):1446-54.

18. Nordin FNM, Mohsain SRAS, Tamizi Sm, Razzak MMA. A review on the sunnah of miswak (Salvadora persica) and its potentiality to improve oral health. Revelation and Science. 2012; 2(1):33-41. 